How to Cite:

Werdistira, I. W. A., \& Purnama, I. G. A. V. (2020). Local wisdom based Balinese digital storytelling through blended learning method. Linquistics and Culture Review, 4(1), 48-54.

https://doi.org/10.37028/lingcure.v4n1.26

\title{
Local wisdom based Balinese digital storytelling through blended learning method
}

\author{
I Wayan Astu Werdistira \\ ITB STIKOM Bali, Denpasar, Indonesia \\ I.G.A. Vony Purnama \\ ITB STIKOM Bali, Denpasar, Indonesia
}

\begin{abstract}
This research was a Research and Development (R\&D) which aimed at developing Local Wisdom based Balinese Digital storytelling through Blended Learning method as an innovative media for teaching writing at Information System Educational Program of ITB STIKOM Bali. The data were collected by using documentation technique, interview, observation, and questionnaire. The collected data were analyzed quantitatively to find out the mean score, in which the mean score was categorized based on the criterion referenced evaluation table. This research found that, (1) In developing Local Wisdom Based Balinese Digital Storytelling Through Blended Learning Method required a chronologically steps, namely: observation, need analysis, designing prototype of the media, expert judgment, revising the product, field testing, analyzing the data and finalizing the final product, (2) furthermore, the result of the questionnaire filled by the students was 3.78, it represented that the implementation of local wisdom based digital storytelling through Blended Learning method could be categorized as good. The results of this study were highly expected can help both the teachers and the students in the process of teaching and learning writing narrative text.
\end{abstract}

Keywords---balinese, blended learning, digital storytelling, local wisdom.

\section{Introduction}

In this global era, the goal of learning English that must be achieved by each student in a school is to be able to do many things that are useful for life and the environment today and in the future with English as a tool for communication. So students need to learn English as one of the important tools in developing self-skills, academically, socially, personally, and vocally. To help students inculcate English habits in taking a variety of concrete actions in their lives, the learning experience that is passed must also be based on the real life. It means that all learning components must be related to the use of English in the real life, with learning resources in the form of texts developed from various sources, oral and written, which are actually used in the social environment of students and the community. So in the learning process, every English lecturer should use the language of instruction in English especially for communicative activities (Alterio \& McDrury, 2003; Brown, 2006). The opportunity to interact using English in the daily learning process is a very important thing to do so, and then language becomes an important part of students' daily lives. Thus students become accustomed to listening, speaking, reading, and writing

Linguistics and Culture Review @ 2020.

Corresponding author: Werdistira, I.W. A.; Email: astu.werdistira@gmail.com

Manuscript submitted: 9 Sept 2020, Manuscript revised: 27 Oct 2020, Accepted for publication: 18 Dec 2020 48 
various expressions that are relevant for carrying out English language learning in the classroom or in the campus environment especially ITB STIKOM Bali.

ITB STIKOM Bali is one the first leading information and communication technology institute in Bali that keep rendering the best services to improve sustainable educational performance as to research and social responsibilities according to the request by related parties. The services provided are based on a mutual concept. The vision is to be to assume leadership in the field of informatics and computer science, both academic and practical, in Bali and Indonesia. ITB STIKOM Bali try to keep struggling and following the dynamic global changes as well as the rapid development of technology (Candiasa, 2010; Harding et al., 2012). Although it belongs to campus which is concerned on teaching and learning about information and communication technology but English also important and needed by them because Technology and English are related each other and worldwide. Students of ITB STIKOM Bali must learn and have good ability in acquiring English language due to every aspects and instruction in computer, internet, further technological things are using English, for example one of newest topic now days in technology are about IoT (Internet of things) and AI (artificial intelligent). All explanation and all about them is in English. It means, if students of ITB STIKOM Bali don't have ability in English, how can they understand about that? So that English is the main point that they must be master when they want to be master in Technology.

The goals of RKPS in teaching English as a foreign language of technology is allow the students to master four integrated skills, such as: listening, speaking, reading, and writing. Besides cognitive skills, the students also required to have competencies both in affective and psychomotor. There are some factors that are needed in attaining the successful of teaching and learning process. Those factors are: the role of lecturer, the role of students, teaching and learning strategy, and the relevant and appropriate material and media for the students. Furthermore, the goal of a language teaching is mainly to enable students to communicate in their target language.

Writing is one of the productive skills that should be mastered by ITB STIKOM' students. The students should be able to communicate in written form accurately to be applied in their daily life. Specifically, in teaching writing narrative text. The students should be able to write with correct grammar, punctuation, and diction. Based on the pre-observation conducted, the researchers found that some ITB STIKOM' students had difficulties in acquiring and learning English. For example, some of them still confused in writing, about how they found an idea to write and how they arranged the idea into paragraph. Most students also had problems in vocabulary and diction.

This phenomenon also caused by several factors such as: the used of conventional method in teaching and learning process, the condition of pre and post activity in class, monotonous course book used also become other aspects that noticed by students, and students also need various ways of teaching to prevent them from being bored when teaching and learning process happened (Hubackova \& Semradova, 2016; Garrison \& Kanuka, 2004; Kaur, 2013). Due to these situations, students have less interest to follow materials given by lecturer in the class. Start to feel bored with this situation and at last they had low competency in using the target language.

The above problems happened in ITB STIKOM Bali. Based on the pre-observation conducted at one of the sample class BE203 Educational Program of Information System, there were some students who encounter mistakes in their writing. They write their sentences ungrammatically, misspelling, and incorrect punctuation. Moreover, their writing organization or development that made it difficult to be understood. The researchers also did an interview with some students. The students said that they felt confuse when they were asked to write. They did not have any idea and they thought it was a very difficult task when they had to develop the topic in the written form. 
Nowadays, the development of technology increases rapidly in any field of our life. It is also happened in education sector, one of the newest technology which is used in the teaching learning process is digital storytelling. By using digital storytelling as a media for teaching writing, the students will have more chance to practice their writing through face to face instruction and distance learning (Santyasa et al., 2019; Sugiyono, 2011; Thohir, 2015). Moreover, students will have new way to learn English, especially to develop their writing skill then hopely will able to help them to acquire English language faster.

This kind of media supports the Blended Learning method in teaching writing. The Blended Learning method combines face to face classroom methods with computermediated activities to form an integrated instructional approach (López-Pérez et al., 2011; Owston et al., 2013). In the past, digital materials have served in a supplementary role, helping to support face to face instruction. Based on the factors and the situation above, the researcher did a research in order to develop local wisdom based Balinese digital storytelling through Blended Learning method as a innovative media for teaching writing at Information System Educational Program of ITB STIKOM Bali.

\section{Method}

This research could be categorized as Research and Development (R\&D). It referred to the evaluating materials in which the findings of the study were used to develop a new product 2 . In relation to the above definition, this research considered as a preliminary research and development $(R \& D)$ since the aim of this research was to design a new product of local wisdom based Balinese digital storytelling through Blended Learning method as a media for teaching writing at Information System educational program of ITB STIKOM Bali.

The design of these media for Information System educational program of ITB STIKOM Bali is adapted from Luther's model (Lowenthal \& Dunlap, 2010; Yang \& Wu, 2012). Then, this draft tried out in the class. In each stage, there were two activities, namely evaluation or review and revision towards the draft. Then, the product of this research was local wisdom based Balinese digital storytelling through Blended Learning method as a media for teaching writing. This media was available in the form of Video.

In relation to the above definition, this research used Luther's model stated that in developing multimedia there were six steps which should be followed, namely; (1) concept, (2) design, (3) material collecting, (4) assembly, (5) testing, and (6) distribution7. Those steps could be explained in the following figure:

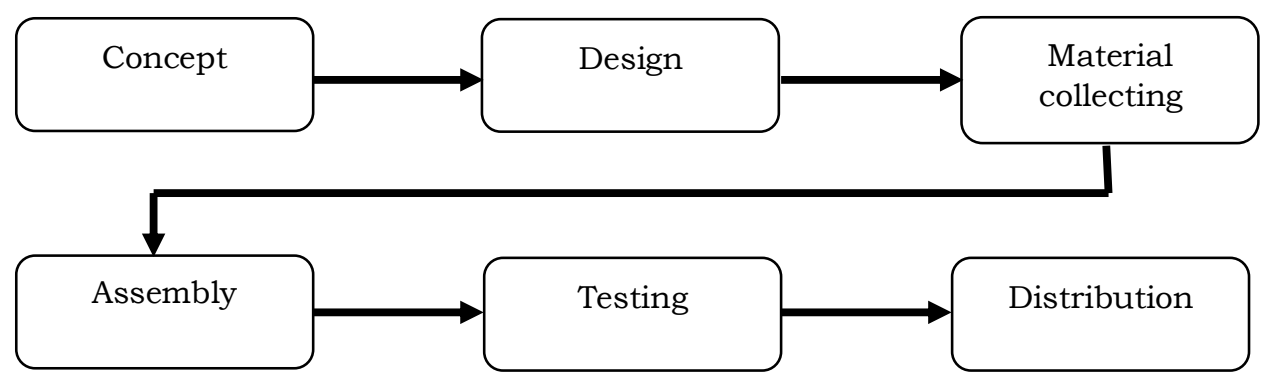

Figure 1. Luther's Model 


\section{Discussion}

The Procedures of Developing Local Wisdom Based Balinese Digital Storytelling through Blended Learning Method.

\section{Observation}

In this part of the study, the researcher conducted an observation at class BE203 Educational program of Information System. The purpose was to identify the problems occurred during the teaching and learning process in the classroom. The material taught in that class was Classify (C3) vocabulary about MP3 Players and Classify (C3) vocabulary about Communications which concerned on reading, writing and speaking skill. During the observation, lecturer taught material based on course book without inserting additional material that can be used for improving students' skill in English and media used only power point. The students were asked to do presentation related to the topics on course book without asked them to elaborate their technology skill and Balinese culture into one point of presentation that they got based on topics (Malita \& Martin, 2010; Campbell, 2012; Schmoelz, 2018). The students did not have any challenging activities during the teaching and learning process. The researcher found that, the students were not motivated enough in the process of teaching and learning. Furthermore, in order to get the comprehensive data the researcher did an interview to the students. All students said that most of the students still confused when they were asked to write in English. Then, they stated that the problem caused by: (1). Materials were not clearly explained, (2). most of the activity in the classroom was doing presentation based on topics that they got so there was no chance for them to elaborate their technology skill based on topic, (3). there was no an innovative media applied by the lecturer.

\section{Need Analysis}

In this step, the researcher did some analysis on the characteristics of English at class BE203 Educational program of Information System, teaching learning process, the existing media for teaching writing, and the characteristics of class BE203 Educational program of Information System.

\section{Designing the Prototype}

In this part of the study, the researcher designed the prototype of the media. There were four steps that should be followed by the researcher, such as: (1). Deciding learning achievement and objective, (2). Deciding indicators, (3). Designing topic of writing materials and activities, and (4). Designing the media.

Based on the limitation of the study, the researcher only focused on the writing narrative text. In this case, the researcher integrated the Balinese local story as the examples of topic that discussed by the students (Pornpimon et al., 2014; Widodo, 2012; Patriadi, et al., 2015). There were some reasons in line with the used of Balinese story, such as: (1). The stories were familiar with the students, (2). To give chances to the students to know, understand, and apply the moral values lying behind the stories, and (3) Asked the students and the teacher to keep the Balinese culture through education. In line with the competency standard and basic competency, the indicators and the objectives that would be developed could be formulated as following:

- Indicators

Able to listen audio MP3 and write English text from MP4 video

- Objectives

a) Create vocabulary in English related to technology 
b) Examine (C4) reading method that appropriate with reading objective in English text.

c) Apply (C3) writing skill in writing simple sentence and short paragraph.

d) A custom (C3) English skill that appropriate with material will be learnt (writing, and listening).

Furthermore, the materials and the activities developed referred to the demand of the curriculum which reflected on the competency standard and basic competency. Besides that, the materials developed were based on the needs of the students and the teacher. The design of the media was made based on the requirement of the competency standard, basic competency, the needs of the students and the teacher. Then the researcher decided to create the media through website, because it can facilitate the teaching and learning process wherever and whenever. In this case, the researcher choose one of the blog software, it was "Wordpress".

\section{Expert Judgment}

The product of this study was a prototype of local wisdom based digital storytelling wisdom through Blended Learning method as a media for teaching writing at BE203 Educational program of Information System in ITB STIKOM Bali. In order to validate the product, the researcher invited three experts to give justifications on the instruments used, the content of the media, and the appearance of the media.

The first instruments judged were the questionnaires for the teacher and the students. There were some suggestions and corrections on the instructions of the questionnaires. The instructions were criticized for having clearer choice of words to make it easier to be understood by the respondents in filling the questionnaire. The next justifications were given by the content media expert. Before judged on the content of the media, the expert criticized on the questionnaire used for the content experts (Usman, et al., 2014; Blackwell \& Colmenar, 1999). There were some corrections given by the expert. There were two additional components of assessment that should be added in the questionnaire, they were: "balikan" and "tata bahasa". Besides that, the expert also commented on the instructions and on the grammar used in the questionnaire.

Based on the calculation of the score given by the content expert, the researcher found that the mean score was 4.73. It indicated that the content of the media was categorized as "excellent". It also meant that the content expert considered the media was acceptable to be applied for teaching writing.

Moreover, the prototype of local wisdom based Balinese digital storytelling Wisdom through Blended Learning method also validated by second expert. Before giving justifications on the media, the expert gave comments and corrections to the questionnaire used for the media expert. In this case, the expert suggested on the components of assessment which was should be more specific one. For instance, the term "Tampilan Media" had to be divided into some specific items, such as: "Pewarnaan, Penggunaan Huruf, Kualitas Gambar".

Based on the result of the questionnaire filled by the media expert above, can be concluded that the local wisdom based digital storytelling through Blended Learning method was categorized as "excellent". It meant that the media was appropriate to be applied for teaching writing.

\section{Final Product}

The final product of this research and development was the local wisdom based Balinese digital storytelling wisdom through Blended Learning method as a media for teaching writing at ITB STIKOM Bali. The product only focused on the writing skill. The media could 
be used through online and offline. In the online form, the media could be accessed on: https://wordpress.com/customize/balinesedigital.wordpress.com.

Student's Responses in Applying the Local Wisdom Based Balinese Digital Storytelling Wisdom through Blended Learning Method as a Media for Teaching Writing. The field test was conducted through online because of COVID 19 Pandemic. The media could be accessed easily by the students in the teaching learning process, because the media was in form of website blog. At this stage the researcher also conducted an observation and gave questionnaires to the students to know how the students' responses to the implementation of the media. There were 15 items in the questionnaire that should be filled by the students.

Based on the result of the questionnaire, the mean score of the questionnaire was 3.78. It means that that the local wisdom based Balinese digital storytelling wisdom through Blended Learning method as a media for teaching writing was categorized "good". In addition, the students' responses of the media were positive. They were interested and motivated while the teaching and learning process by using the media.

\section{Conclusion}

There were some steps which should be followed in developing the Local Wisdom Based Balinese Digital Storytelling through Blended Learning Method as a media for teaching writing, such as: (1). Observation at students in Information System educational program of ITB STIKOM Bali to identify the problems, (2). Did some analysis in order to identify the needs of the students and the teacher, (3). Designing the prototype of the media, (4). Expert judgment, (5). Revising the product based on the expert's corrections, (6). Field testing, (7). Analyzing the data and revising the product, and (8). Finalizing the product; Furthermore, the students also were given an opportunity to give responses about the media. In this case, the researcher also delivered questionnaires to each student after the process of the teaching and learning. After calculating the results of the questionnaire, the total of the mean score was 3.78. It indicated that, the media was "good" for teaching writing at Information System educational program of ITB STIKOM Bali.

\section{Acknowledgments}

We would like to appreciate those who are contributing and also supporting this research especially ITB STIKOM Bali. The manuscript was written to fulfill the requirement of ITB STIKOM Bali internal research program. The authors declare that there is no difference of interest regarding publication of this article.

\section{References}

Alterio, M., \& McDrury, J. (2003). Learning through storytelling in higher education: Using reflection and experience to improve learning. Routledge.

Blackwell, A., \& Colmenar, R. (1999). Transforming policy through local wisdom. Futures, 31(5), 487-497. https://doi.org/10.1016/S0016-3287(99)00008-7

Brown, J. S. (2006). New learning environments for the 21st century: Exploring the edge. Change: The magazine of higher learning, 38(5), 18-24.

Campbell, T. A. (2012). Digital storytelling in an elementary classroom: Going beyond entertainment. Procedia-Social and Behavioral Sciences, 69, 385-393. https://doi.org/10.1016/i.sbspro.2012.11.424

Candiasa, I. (2010). Statistik Univariat dan Bivariat disertai aplikasi SPSS. Singaraja: Unit Penerbitan Universitas Pendidikan Ganesha.

Garrison, D. R., \& Kanuka, H. (2004). Blended learning: Uncovering its transformative potential in higher education. The internet and higher education, 7(2), 95-105. https://doi.org/10.1016/j.iheduc.2004.02.001 
Harding, A., Kaczynski, D., \& Wood, L. (2012). Evaluation of blended learning: analysis of qualitative data. In Proceedings of The Australian Conference on Science and Mathematics Education (formerly UniServe Science Conference) (Vol. 11).

Hubackova, S., \& Semradova, I. (2016). Evaluation of blended learning. Procedia-Social and Behavioral Sciences, 217, 551-557. https://doi.org/10.1016/j.sbspro.2016.02.044

Kaur, M. (2013). Blended learning-its challenges and future. Procedia-Social and Behavioral Sciences, 93, 612-617. https://doi.org/10.1016/j.sbspro.2013.09.248

López-Pérez, M. V., Pérez-López, M. C., \& Rodríguez-Ariza, L. (2011). Blended learning in higher education: Students' perceptions and their relation to outcomes. Computers \& education, 56(3), 818-826. https://doi.org/10.1016/.j.compedu.2010.10.023

Lowenthal, P. R., \& Dunlap, J. C. (2010). From pixel on a screen to real person in your students' lives: Establishing social presence using digital storytelling. The Internet and Higher Education, 13(1-2), 70-72. https://doi.org/10.1016/j.iheduc.2009.10.004

Malita, L., \& Martin, C. (2010). Digital storytelling as web passport to success in the 21st century. Procedia-Social and Behavioral Sciences, 2(2), 3060-3064. https://doi.org/10.1016/i.sbspro.2010.03.465

Owston, R., York, D., \& Murtha, S. (2013). Student perceptions and achievement in a university blended learning strategic initiative. The Internet and Higher Education, 18, 38-46. https://doi.org/10.1016/j.iheduc.2012.12.003

Patriadi, H. B., Bakar, M. Z. A., \& Hamat, Z. (2015). Human security in local wisdom perspective: pesantren and its responsibility to protect people. Procedia Environmental Sciences, 28, 100-105. https://doi.org/10.1016/i.proenv.2015.07.015

Pornpimon, C., Wallapha, A., \& Prayuth, C. (2014). Strategy challenges the local wisdom applications sustainability in schools. Procedia-Social and Behavioral Sciences, 112, 626-634. https://doi.org/10.1016/.j.sbspro.2014.01.1210

Santyasa, I. W., Kanca, I. N., Warpala, I. W. S., \& Sudarma, I. K. (2019). Group Investigation and Explicit learning Models in Learning Physics at Senior High Schools. Jurnal Penelitian \& Pengembangan Pendidikan Fisika, 5(2), 203-216.

Schmoelz, A. (2018). Enabling co-creativity through digital storytelling in education. Thinking Skills and Creativity, 28, 1-13. https://doi.org/10.1016/j.tsc.2018.02.002

Sugiyono, (2011). Metode Penelitian Kuantitatif, Kualitatif, dan R\&D. Bandung: Alfabeta

Thohir, A. (2015). Pendidikan Karakter Berbasis Local Wisdom. Wartamadani.

Usman, F., Murakami, K., \& Kurniawan, E. B. (2014). Study on reducing tsunami inundation energy by the modification of topography based on local wisdom. Procedia Environmental Sciences, 20, 642-650. https://doi.org/10.1016/i.proenv.2014.03.077

Widodo, J. (2012). Urban environment and human behaviour: learning from history and local wisdom. Procedia-Social and Behavioral Sciences, 42, 6-11. https://doi.org/10.1016/i.sbspro.2012.04.161

Yang, Y. T. C., \& Wu, W. C. I. (2012). Digital storytelling for enhancing student academic achievement, critical thinking, and learning motivation: A year-long experimental study. Computers \& education, 59(2), https://doi.org/10.1016/j.compedu.2011.12.012 